\title{
DE
}

DE GRUYTER

OPEN

DOI: 10.1515/jolace-2016-0030

\section{A corpus-based analysis of textbooks used in the orientation course for immigrants in Germany: Ideological and pedagogic implications}

\author{
Ray C. H. Leung, University of Potsdam, Germany \\ chungleungde@gmail.com
}

\begin{abstract}
Contextualized within immigrants' acquisition of specialized knowledge about the host country at the institutional level, this article examines a 64295-word corpus of textbooks written for participants of the orientation course in German politics, history and culture. Corpus-based techniques ("keyness," collocation and qualitative examination of concordance lines) are deployed to explore the corpus. The findings reveal that the collocational patterns of the identified keywords construct particular world views vis-à-vis Germany. For instance, the keyword DDR [German Democratic Republic (GDR), aka East Germany] frequently co-occurs with negatively connoted lexis while collocates of the keywords denoting present-day Germany (e.g., Bundesrepublik Deutschland [Federal Republic of Germany] and Staat [nation, country, state]) facilitate the portrayal of Germany as a nurturing welfare state that is popular among foreigners. It is argued that such discursively-construed opposition between the "bad" GDR and the "good" Federal Republic of Germany helps to legitimize the German reunification. Furthermore, it is found that certain keywords (e.g., Sie [you], Kurs [course, class] and z.B. [e.g.]) are "metadiscourse resources" (Hyland, 2005). Their pedagogic effects are discussed in relation to the ideological implications of the research findings.
\end{abstract}

Key words: orientation course; immigrants; Germany; corpus linguistics; textbooks; ideologies

\section{Introduction}

In 2015 Germany and its chancellor Angela Merkel received global attention due to her compassionate stance on the issue of immigration which led to the substantial surge in asylum seekers from Syria (Hutton, 2015). Apart from asylum seekers, many foreigners have moved to Germany in recent years for a variety of purposes such as work and family reunification. According to the Federal Statistical Office of Germany (2016), the foreign population in Germany reached 9 million at the end of 2015. Immigration is actually not a new topic in Germany. As Wegmann (2014, p. 132) pointed out, Germany was an important host country of 
foreign guest workers (e.g., Italians, Turkish, Greeks, etc.) after the Second World War, resulting in many immigrant families. This marked the commencement of immigration in contemporary German history. Starting from 2004, the German government began to set integration of immigrants as its priority and the Federal Office for Migration and Refugees was established to manage issues related to immigration. One measure taken by the office to enhance integration of immigrants is the implementation of the compulsory integration course (p. 134). The integration course consists of two main components-a 600-hour German language course ${ }^{1}$ (Sprachkurs) and a 60-hour orientation course (Orientierungskurs). The orientation course, which takes place after the completion of the German language course, is about the German political system, history and culture. At the end of the orientation course, participants will sit the "Living in Germany" (Leben in Deutschland) examination. Passing the examination is a prerequisite for naturalization (Federal Office for Migration and Refugees, 2016b).

The present research will capitalize on analytic tools ("keyness," collocation and qualitative examination of concordance lines) from corpus linguistics to examine three selected textbooks (totaling 64295 running words) designed for the orientation course. More information about the corpus and the methods used for data analysis will be given in Data and Methodology. To the best of my knowledge, no prior researchers have specifically conducted a corpus-based analysis of educational materials for immigrants in Germany. Most of the relevant research performed so far is related to textbooks used by overseas learners of German as a foreign language (e.g., Byram, 1993; Lipinski, 2010; Snider, 2005) or students in German local schools (e.g., Bottici \& Challand, 2013; Moser \& Hannover, 2014). The shortage of comparable previous research provides a strong justification for carrying out the current study. There are two further reasons which make the present research worthwhile. First, textbooks, as van Dijk (2008, p. 62) remarked, are "powerful" discourse because students are obliged to read them and the contents of such materials embed a "dominant consensus" or are geared towards the interests of the most powerful social groups. Attending the orientation course (which entails the use of textbooks) is a form of knowledge acquisition for the immigrants. While such knowledge may be "general" or "commonsensical" for most German citizens, it can be new and unfamiliar ("specialized knowledge") for the immigrants. Acquisition of the specific knowledge about Germany not only marks the immigrants' membership in the German community, but it also enables them to comprehend public discourse (e.g., news reports) in Germany (van Dijk,

1 Participants of the German language course are expected to graduate with B1 German language proficiency under the Common European Framework of Reference for Languages (Federal Office for Migration and Refugees, 2016c). 
2014, p. 136). It is hoped that the present research will shed light on the ideological implications associated with the use of the textbooks. Secondly, the orientation course is basically offered to learners of German as a foreign language. As earlier corpus-based research on textbooks (e.g., Lam, 2009; Neary-Sundquist, 2015; Wood \& Appel, 2014) has shown, they tend to contain specific lexical or phrasal patterns of language use which have pedagogic implications. This is what I would like to explore in the current study as well.

\section{Literature review}

Depending on its focus, previous corpus-based research on textbooks can generally be classified into two types (or a combination of both): (i) one that reveals the ideological implications of the textbooks (e.g., the representation of particular events or social/cultural groups); (ii) one that contributes to language education (viz., patterns regarding the use of certain linguistic features). It is not possible to review all the relevant studies here. I will provide an overview of some of them, especially those relevant to the German context.

Byram's (1993) work is made up of content analysis on five series of textbooks for learners of German as a foreign language outside Germany. Byram (1993, pp. 34-35) focused on evaluating the textbooks' potential to aid the development of intercultural awareness. The textbooks were assessed in accordance with eight criteria, one of which is "national history." Noticeable differences were identified across the textbook series. For instance, cultural contents are better integrated into the learning of vocabulary and grammar in certain textbooks than the others. Byram (1993, p. 196) concluded that more uniformity across the textbook series is necessary. Despite its comprehensiveness, techniques from corpus linguistics were not applied in the work of Byram (1993) so it lacks the support of empirical linguistic evidence. Similar to Byram (1993), Lipinski (2010) analyzed three textbooks for beginners of German as a foreign language. The objective of the research, which was oriented towards pedagogy, was to cast light on the use of vocabulary in the textbooks. By using an established frequency list of German for data analysis, Lipinski (2010) found a noticeable amount of low-frequency words used in the textbooks. She argued that these words, which tend to be rarely used in daily life, should be avoided in order to minimize an "overload of students' capacities" (p. 173). Interested in the formation of present-day European identity, Bottici and Challand (2013, pp. 57-61) compared history textbooks used in three founding members of the European Union-Germany, Italy and France. The findings show that Italian textbooks are very unwilling to favor the interpretation of Europe as "born out of the Second World War" whereas German textbooks are more inclined to do so, as evidenced by the use of lexical items such as Vergangenheitsbewältigung (acceptance of the past) and Erinnerungsarbeit 
(memory work) to attribute the European integration process to the experience of the war.

Research which explicitly employed corpus-based techniques to examine textbooks can be identified as well. Two examples from the Asian contexts are the research of Fraysse-Kim (2010) and that of Hong and He (2015). Fraysse-Kim (2010) compared Korean language textbooks adopted in elementary schools across four geographical regions. Keywords which signal national consciousness of Koreans were identified in order to study their collocational patterns. ${ }^{2}$ FraysseKim (2010, p. 225) found that a common pattern among all the textbooks is the strong collocation of the words wuli (we, our) and mal (language). Also, the word ilbon (Japan) tends to contain negative connotation. It was suggested that these findings show how the Korean collective identity is forged and reproduced in textbooks. Hong and He (2015) studied how cultural and ethnic diversity is represented in Chinese language textbooks endorsed by the Confucius Institute (the Chinese equivalent of organizations like the British Council and the GoetheInstitut which promote the learning of the target language worldwide). Frequency counts regarding the linguistic expressions which trigger ethnic and cultural themes were conducted. It was discovered that the Han ethnic group is overrepresented while the minority groups are subject to marginalization (pp. 97-99). Hong and He (2015) believed that the textbooks fail to offer a representation of multiculturalism in contemporary Chinese culture.

The review of the relevant empirical studies has demonstrated that textbooks constitute a well-researched area in academia. However, none of the studies mentioned in this section has directly addressed the issue vis-à-vis the institutional socialization of immigrants through textbooks or discourse of similar nature. It is hoped that the current research will be able to fill this gap in the literature.

\section{Data and methodology}

The corpus of this study was compiled from three textbooks written specifically for the orientation course in Germany. They were published by different publishers, which also produced a wide array of course materials for learners of German. Details of these three textbooks can be found in Table 1.

In order to analyze the keywords of the corpus, AntConc 3.5.0 (Anthony, 2015) was used to generate the keyword list. In corpus linguistics, keywords are words of a corpus (viz., the study corpus) which appear significantly more often in comparison with a reference corpus. The term "keyness" is a statistical measure of how salient a word is in a given corpus. Thus, it is suggested that the keyword list

\footnotetext{
2 More information about the notions of "keywords" and collocation, which form part of the analytic framework of the present research, will be given in the following section.
} 
of a corpus can provide researchers with ideas of the "aboutness" of the corpus (Cheng, 2012, p. 70).

Table 1: Corpus of textbooks for the present research

\begin{tabular}{|c|c|c|c|c|c|c|}
\hline & Title & $\begin{array}{l}\text { Abbre- } \\
\text { viation }\end{array}$ & $\begin{array}{l}\text { Year of } \\
\text { Publication }\end{array}$ & $\begin{array}{l}\text { Publi- } \\
\text { sher }\end{array}$ & $\begin{array}{l}\text { Number } \\
\text { of pages }\end{array}$ & $\begin{array}{l}\text { Number of } \\
\text { words }\end{array}$ \\
\hline 1 & $\begin{array}{l}60 \text { Stunden } \\
\text { Deutschland }\end{array}$ & $60 S D$ & 2013 & Klett & 96 & $\begin{array}{l}22157 \\
(34.46 \%)\end{array}$ \\
\hline 2 & Orientierungskurs & $O K$ & 2014 & Cornelsen & 91 & $\begin{array}{l}21042 \\
(32.73 \%)\end{array}$ \\
\hline 3 & $\begin{array}{l}\text { Zur Orientierung: } \\
\text { Basiswissen } \\
\text { Deutschland }\end{array}$ & $Z O$ & 2014 & Hueber & 86 & $\begin{array}{l}21096 \\
(32.81 \%)\end{array}$ \\
\hline \multicolumn{6}{|r|}{ Total } & $\begin{array}{l}64295 \\
(100 \%)\end{array}$ \\
\hline
\end{tabular}

As noted by Culpeper and Demmen (2015, p. 97), the reference corpus is normally as large as or even very much larger than the study corpus. A typical example is the British National Corpus (BNC) which consists of 100 million words. Finding a reference corpus for the present research posed a real challenge. The reason is that users of AntConc 3.5.0 must upload either the entire reference corpus or a tailor-made word frequency list of that corpus to the software program before the keyword list can be obtained. Existing corpora of German language such as the German Reference Corpus (Deutsches Referenzkorpus) housed by the Institute of German Language allow researchers to perform user-specific searches only and are not available for download. I had to resort to looking for the word frequency list of a reference corpus instead. However, this word frequency list must be in a particular format in order for it to be read by AntConc 3.5.0. Unlike their English counterparts, such lists for German are not widely accessible. In the end, the one made by Krummes (2013) from the corpus "internet-de" was found and chosen. This corpus, which is made up of more than 100 million words, was compiled by researchers from the University of Leeds. Although the corpus is a collection of texts on the Internet, a specific procedure was followed during text selection so as to make the corpus "balanced" (Sharoff, 2006).

As said by Culpeper and Demmen (2015, p. 99), "keyness" is only the initial statistical step to analyze texts in corpus linguistics. Once the keyword list of the present corpus was generated, the keywords were grouped on the basis of semantic domains. This would pave the way for a systematic analysis. The "collocational profiles" (Jaworska \& Krishnamurthy, 2012) of the keywords were then analyzed. Collocation may broadly refer to the recurrent co-occurrence of words. Two types of collocates (i.e., "wider collocates" and "immediate collocates") are distinguished (Wolf \& Juffermans, 2008). In general, "wider collocates" are 
words which appear within a span of five words on either side of a specified word while "immediate collocates" denote adjacent words (p. 136). Like "keyness," there are statistical tests which measure the degree of collocation between words. The common ones are the mutual information (MI) and the t-score tests. Although these two tests are both available in AntConc 3.5.0, I selected the t-score test for this study. In fact, cross-checks were performed with the MI test but many of the top MI-identified collocates are low-frequency words which occur only one time throughout the corpus, hence insufficient for insightful analysis.

Qualitative examination of the relevant concordance lines was later carried out. Manual checks on the concordance lines were needed in order to unfold the ideological or pedagogic implications associated with the use of certain lexical items. During this process, attention was paid to the "semantic prosody" - the attitudinal meanings arising from the neighborhood of specific words in discourse (Sinclair, 2003, p. 178).

\section{Findings and discussion}

As pointed out by Culpeper and Demmen (2015, p. 97), the two statistical tests for "keyness" (viz., Chi-Square and Log-Likelihood) produce highly similar results with merely unimportant differences in the ranking of the identified keywords and such differences do not affect the general picture derived from the keyword list. In light of this, the default option offered by AntConc 3.5.0 (i.e., Log-Likelihood) was chosen. Table 2 displays the first 23 keywords $^{3}$ obtained.

Before going into detail, I have to first clarify that the keyword search was performed in a case-sensitive manner. The use of initial capital letters in German is different from that in English. As remarked by Durrell (2011, pp. 506-507), initial capital letters apply to four types of words: (i) those which start a sentence; (ii) all nouns; (iii) the formal second person pronoun Sie [you] and all its grammatical variants (e.g., Ihnen [dative form of Sie], Ihr [possessive determiner of Sie], etc.); (iv) proper names. The third type poses a challenge to concordancing and keyword generation, given the fact that the third person feminine pronoun and the third person plural pronoun carry the orthographic form sie without initial capitalization. If case-sensitivity had been disregarded during the keyword search, the difference in meanings between Sie [you] and sie [she or they] would have been completely overlooked. In other words, the results would have been distorted.

${ }^{3}$ In order to have a focused analysis, I intended to single out the first 20 lemmas of the keyword list for discussion. However, the list given by AntConc 3.5.0 is not "lemmatized" and some of the keywords are simply grammatical variants of the others (i.e., Bundeskanzlerin and Bundeskanzler; Bundesland and Bundesländer; Grundgesetz and Grundgesetzes). After manual checking, it has been found that the first 23 keywords of the list constitute 20 different lemmas. 
Although the case-sensitive search did not exclude situations where sie [she or they] is the first word of a sentence, it could at least mitigate the potential distortion of the results, making subsequent manual checks on the relevant concordance lines more manageable. In fact, manual checks have revealed that instances of sie [she or they] being the first word of a sentence are relatively infrequent. More information about this will be provided later

Table 2: First 23 keywords in the corpus of textbooks

\begin{tabular}{|c|c|c|c|c|}
\hline \multirow[t]{2}{*}{ Rank } & \multicolumn{2}{|r|}{ Keywords } & \multirow[t]{2}{*}{ *Freq. } & \multirow[t]{2}{*}{ Keyness } \\
\hline & $\begin{array}{l}\text { German } \\
\text { original }\end{array}$ & English translation & & \\
\hline 1 & Sie & $\begin{array}{ll}\text { - } & \text { you (formal) } \\
\text { - } & \text { she (at the start of a sentence) } \\
\text { - } & \text { they (at the start of a sentence) }\end{array}$ & 1419 & 3193.412 \\
\hline 2 & Deutschland & Germany & 641 & 2390.399 \\
\hline 3 & $z . B$. & e.g. & 144 & 1307.930 \\
\hline 4 & Welche & which (question word) & 185 & 973.837 \\
\hline 5 & Ordnen & to order (imperative polite form) & 59 & 830.345 \\
\hline 6 & Kreuzen & to cross (imperative polite form) & 56 & 788.124 \\
\hline 7 & Lesen & to read (imperative polite form) & 132 & 727.771 \\
\hline 8 & $D D R$ & German Democratic Republic & 143 & 708.679 \\
\hline 9 & Bundesrepublik & Federal Republic & 142 & 691.164 \\
\hline 10 & $\begin{array}{l}\text { Bundeskanzleri } \\
n\end{array}$ & Federal Chancellor (feminine) & 47 & 661.462 \\
\hline 11 & Was & what (question word) & 265 & 567.936 \\
\hline 12 & Bundestag & Federal Parliament & 107 & 565.314 \\
\hline 13 & Staat & nation, country & 166 & 552.459 \\
\hline 14 & Kurs & course, class & 108 & 551.389 \\
\hline 15 & Grundgesetz & German constitution & 71 & 438.526 \\
\hline 16 & Gesetze & laws, legislation (plural) & 96 & 427.004 \\
\hline 17 & Bundesland & federal state & 52 & 365.963 \\
\hline 18 & Ergänzen & $\begin{array}{l}\text { to complete (imperative polite } \\
\text { form) }\end{array}$ & 26 & 365.915 \\
\hline 19 & Bundesländer & federal states (plural) & 58 & 361.032 \\
\hline 20 & Bundeskanzler & Federal Chancellor (masculine) & 71 & 351.176 \\
\hline 21 & Grundgesetzes & German constitution (dative form) & 49 & 330.225 \\
\hline 22 & Menschen & people (plural) & 266 & 329.030 \\
\hline 23 & Kinder & children (plural) & 174 & 316.045 \\
\hline
\end{tabular}

*Frequency: Number of occurrences identified within the entire corpus 
By following the way Gerbig (2010, p. 152) systematized keyword analysis in her study, the keywords identified and illustrated in Table 2 are grouped manually into 9 sets of "semantically related words." The groupings are exhibited via Table 3.

Table 3: The 9 dimensions along which the first 23 keywords are grouped

\begin{tabular}{|l|l|l|l|}
\hline Number & Dimension & Keywords & $\begin{array}{l}\text { Number of } \\
\text { keywords }\end{array}$ \\
\hline 1 & Government & $\begin{array}{l}\text { Bundeskanzlerin, Bundestag, Staat, } \\
\text { Bundesland, Bundesländer, } \\
\text { Bundeskanzler }\end{array}$ & 6 \\
\hline 2 & Processes & Ordnen, Kreuzen, Lesen, Ergänzen & 4 \\
\hline 3 & Germany & Deutschland, Bundesrepublik, DDR & 3 \\
\hline 4 & Law & Grundgesetz, Gesetze, Grundgesetzes & 3 \\
\hline 5 & $\begin{array}{l}\text { Question } \\
\text { word }\end{array}$ & Welche, Was & 2 \\
\hline 6 & $\begin{array}{l}\text { General } \\
\text { public }\end{array}$ & Menschen, Kinder & 2 \\
\hline 7 & Pronoun & Sie & 1 \\
\hline 8 & $\begin{array}{l}\text { Abbreviated } \\
\text { adverbial }\end{array}$ & z.B. & 1 \\
\hline 9 & Learning & Kurs & 1 \\
\hline
\end{tabular}

Given the syllabus of the Orientierungskurs, the prominence of Dimension 1 (Government), Dimension 3 (Germany) and Dimension 4 (Law) is not surprising because they are all related to the German political and social contexts. Among these three dimensions, the one with the keywords referring to Germany (i.e., Deutschland [Germany], Bundesrepublik [Federal Republic], DDR [German Democratic Republic]) is worth special attention because the collocational environment of these words, due to their direct reference to Germany, is highly relevant to the study of how Germany is represented in the textbooks.

Since the full name of present-day Germany is the Federal Republic of Germany (Bundesrepublik Deutschland), it is expected that the keyword Deutschland is a strong collocate of Bundesrepublik at $\mathrm{N}+1$. The collocation analysis (see Table 4) confirms this and it also demonstrates that within the corpus, $D D R$ is a "wider collocate" (viz., within the span of $\mathrm{N}-5$ and $\mathrm{N}+5$ ) of Deutschland and Bundesrepublik, and vice versa. 
Table 4: Statistical significance vis-à-vis the co-occurrence of Deutschland, Bundesrepublik and DDR within the span of $\mathrm{N}-5$ and $\mathrm{N}+5$

\begin{tabular}{|l|l|l|}
\hline Node & Collocate & T-score \\
\hline \multirow{3}{*}{ Beutschland } & Bundesrepublik & 11.88 \\
\cline { 2 - 3 } & DDR & 5.76 \\
\hline \multirow{2}{*}{ DDR } & Deutschland & 11.84 \\
\cline { 2 - 3 } & DDR & 5.78 \\
\hline & Bundesrepublik & 5.78 \\
\cline { 2 - 3 } & Deutschland & 5.67 \\
\hline
\end{tabular}

DDR is the acronym of Deutsche Demokratische Republik. In English, it stands for the German Democratic Republic (GDR) - the Soviet-oriented administration which existed between 1949 and 1990 in the eastern part of Germany (commonly referred to as East Germany). Examination of the concordance lines shows that the co-occurrence of $D D R$ and Bundesrepublik Deutschland tends to concern the German reunification. Some examples are:

(1) Am 3.10.1990 tritt die DDR der Bundesrepublik Deutschland bei. Dieser Tag ist heute Nationalfeiertag. ( $Z O$, p. 75$)$

On 3 October 1990 the GDR joins ${ }^{5}$ the Federal Republic of Germany. This day is the national holiday today.

(2) Einheit: Zusammenschluss der Bundesrepublik Deutschland und der DDR am 3. Oktober 1990. (OK, p.84)

Unification: The merge of the Federal Republic of Germany and the GDR on 3 October 1990.

(3) Am Anfang der achtziger Jahre gibt es sowohl in der DDR als auch der Bundesrepublik Deutschland eine große Friedensbewegung. (OK, p. 41)

At the beginning of the 80 s there is a huge peace movement in both the GDR and the Federal Republic of Germany.

(4) Am 3. Oktober 1990 kommt es zur Vereinigung der DDR und der Bundesrepublik Deutschland. (ZO, p. 64)

On 3 October 1990 it comes to the unification of the GDR and the Federal Republic of Germany.

The GDR is portrayed as the party which was dissolved and became part of the Federal Republic of Germany after the reunification. This is evidenced by Example 5 below.

\footnotetext{
${ }^{4}$ A t-score of at least 2 is considered significant (Cheng, 2012, p. 94).

5 It is not uncommon to apply the present tense to talk about historical events in German.
} 
(5) Am 3. Oktober gibt es die DDR nicht mehr. Sie wird Teil der Bundesrepublik Deutschland. (60SD, p. 56)

On 3 October there is no more GDR. It becomes part of the Federal Republic of Germany.

This example conveys the covert power difference between East Germany and West Germany. Such power difference concerning these two German states in the course of the reunification can be illustrated by analogy with business amalgamation. During a takeover or an acquisition, the company with less power (usually more financial problems) is absorbed by the one with more power. It has been found that numerous concordance lines for DDR (47 out of 143) carry negatively connoted words (e.g., Protesten und Streiks [protests and strikes], schrecklich [awful], Diktatur [dictatorship], Flüchtlinge [refugees] and Einparteienstaat [one-party state]), resulting in a generally negative "semantic prosody" (Sinclair, 2003, p. 178) of the word DDR. Some examples extracted from the corpus are:

(6) Am 17. Juni 1953 kommt es in der DDR zu Protesten und Streiks. (60SD, p. 54)

On 17 June 1953 protests and strikes happen in the GDR.

(7) Die Bilder vom Volksaufstand in der DDR waren ja schrecklich. (60SD, p. 54) The pictures of the popular uprising in the GDR were awful.

(8) Die DDR verändert sich politisch von einer Diktatur zu einer Demokratie. (60SD, p. 56)

The GDR changes politically from a dictatorship to a democracy.

(9) Wie sind die DDR-Flüchtlinge im Sommer 1989 in die Bundesrepublik Deutschland gekommen? (OK, p. 43)

How have the GDR-refugees come to the Federal Republic of Germany in the summer of 1989 ?

(10)Ein Einparteienstaat ist ein Staat, in dessen Parlament nur eine Partei vertreten ist. Beispiele in Deutschland waren der nationalsozialistische Einparteienstaat (1933 bis 1945) und die DDR. (ZO, p. 81)

A one-party state is a state in which only one party is represented in its Parliament. Examples in Germany were the national socialist one-party state (1933 through 1945) and the GDR.

By using the terminology of critical stylistics regarding equivalence and opposition (Jeffries, 2010, pp. 51-55), it can be said that Example 8 makes use of "transitional opposition" (as linguistically manifested by the expression "von X zu Y" ["from X to Y"]). This strategy explicitly constructs the difference which the reunification brought about to the GDR. By contrast, in Example 10 the GDR is "equated" to the Nationalsozialismus [Nazi] regime on the basis of their being a 
one-party state (such equivalence being triggered by the conjunction und [and]). As suggested by Fairclough (2003, p. 88), setting up equivalence and/or differences between groups of people and entities in discourse is a feature of the "continuous social process of classification," which effectively "operationalizes" political hegemony. Here, "value assumptions" (Fairclough, 2003, p. 55) come into play as well. Something undesirable (i.e., the GDR and dictatorship) has to be removed and replaced by its desirable counterpart (i.e., the Federal Republic of Germany and democracy).

Within the corpus, a contrast is often drawn between the GDR and the Federal Republic of Germany in the pre-reunification era. One example is:

(11) Im Gegensatz zu den Westzonen erhält die Sowjetische Besatzungszone in der Nachkriegszeit keine Wirtschaftshilfe. Die Siegermacht Sowjetunion lässt Fabriken und Eisenbahnschienen abbauen und in die Sowjetunion schicken. Deshalb ist der wirtschaftliche Wiederaufbau schwieriger und langsamer als in der Bundesrepublik Deutschland. (60SD, p. 54)

In contrast to the Western zones, the Soviet Occupation Zone receives no economic assistance in the post-war period. The victorious power Soviet Union dismantles factories and railway tracks and sends them to the Soviet Union. Therefore the economic recovery is more difficult and slower than in the Federal Republic of Germany.

In this example, "explicit opposition" (im Gegensatz zu [in contrast to]) and "comparative opposition" (schwieriger und langsamer als [more difficult and slower than]) can be identified. These linguistic triggers help to underline the difference between the GDR and the Federal Republic of Germany.

One may argue that negative associations of the GDR are quite self-evident. Surprisingly, the predominantly negative portrayal of the GDR in the textbooks of the present study deviates from the findings of Vanstone and Mennecke (1993, p. 85). The two researchers found that in Deutsch konkret (a textbook for learners of German as a foreign language on the international market), a more comprehensive or neutral representation of the GDR is given. What is more, as Kupferberg (2002, p. 176) discovered, public sentiment on the GDR is a complex topic which goes far beyond the simplistic evaluation "Everything was bad in the GDR." At this point, I want to emphasize that my purpose is not to question the validity of historical facts or to deny the presence of social problems in the GDR. Instead, examination of the concordance lines for the keyword $D D R$ has shown that a one-sided perspective concerning the GDR is presented via the use of negatively connoted lexis and syntactic triggers of equivalence and opposition. As van Leeuwen (2008, p. 112) argued, evaluation-laden lexis and comparisons in discourse frequently perform a legitimating function. In this case, they are used to legitimize the German 
reunification or, more specifically, the removal of the GDR and its subsequent integration into the Federal Republic of Germany.

Compared to $D D R$, the keyword Deutschland [Germany] tends to conjure up a different image of contemporary Germany. Table 5 captures the "immediate collocates" (at $\mathrm{N}-1$ and $\mathrm{N}+1$ ) of Deutschland.

Table 5: "Immediate collocates" of Deutschland

\begin{tabular}{|l|l|l|l|l|l|}
\hline \multicolumn{2}{|l|}{ N-1 } & \multicolumn{3}{c|}{ N+1 } \\
\hline Collocate & $\begin{array}{l}\text { Joint } \\
\text { frequency }\end{array}$ & T-score & Collocate & $\begin{array}{l}\text { Joint } \\
\text { frequency }\end{array}$ & T-score \\
\hline $\begin{array}{l}\text { in } \\
{[\text { in] }}\end{array}$ & 319 & 17.05 & $\begin{array}{l}\text { ist } \\
{[\text { is] }}\end{array}$ & 42 & 5.43 \\
\hline $\begin{array}{l}\text { Bundesrepublik } \\
\text { [Federal } \\
\text { Republic] }\end{array}$ & 126 & 11.09 & $\begin{array}{l}\text { gekommen } \\
\text { [come (past } \\
\text { participle) }\end{array}$ & 10 & 3.11 \\
\hline $\begin{array}{l}\text { ganz } \\
\text { [all, whole] }\end{array}$ & 26 & 5.01 & $\begin{array}{l}\text { gibt } \\
\text { [give, there } \\
\text { is/are] }\end{array}$ & 14 & 3.07 \\
\hline $\begin{array}{l}\text { nach } \\
\text { [after, to }{ }^{8}\end{array}$ & 27 & 4.81 & $\begin{array}{l}\text { und } \\
\text { [and] }\end{array}$ & 40 & 3.01 \\
\hline & & $\begin{array}{l}\text { was } \\
\text { [what] }\end{array}$ & 13 & 2.69 \\
\hline
\end{tabular}

At $\mathrm{N}-1$, in [in] and Bundesrepublik [Federal Republic] are not surprising collocates of Deutschland. It is common that the preposition of location "in" is used for names of countries and the strong association between Bundesrepublik and Deutschland has been mentioned above. Thus, I will not discuss these two collocates in detail. The other two collocates ganz [all, whole] and nach [after, to] present some noteworthy patterns. Inspection of the concordance lines reveals that the two-word cluster ganz Deutschland [all/whole Germany] is often used in contexts where the German political system and social policies are described. Some examples are:

6 The threshold for the minimum joint frequency is at 10.

7 The verb geben (the infinitive form of gibt [give]) is commonly used to denote existence. This is signaled by the impersonal construction es gibt [there is/are] (Durrell, 2011, p. 360).

8 The German preposition nach has two meanings. In the sentence Nach der Hochzeit fliege ich nach Hongkong [After the wedding I fly to Hong Kong], the first occurrence of nach is a preposition of time whereas the second instance is a preposition of movement. 
(12) Ziele der Gewerkschaften sind Tarifverträge, die in ganz Deutschland gelten und höhere Löhne. (60SD, p.39)

Goals of the labor unions are wage agreements, which apply in whole Germany, and higher pay.

(13) Das Parlament für ganz Deutschland ist der Bundestag. (OK, p. 87) The parliament for whole Germany is the Bundestag [Federal Parliament].

(14) Im Parlament treffen sich die Abgeordneten aus ganz Deutschland und diskutieren über die Politik der Bundesregierung. Sie werden von allen Deutschen gewählt. (ZO, p. 11)

In the parliament the delegates from whole Germany meet together and discuss the politics of the federal government. They [the delegates] are elected by all Germans.

Germany is now composed of 16 federal states and each state can practice some levels of autonomy over its internal affairs. Besides, Germany was split up by the allies after the Second World War and was then divided into East and West Germany before the fall of the Berlin Wall in 1989 (The World Factbook, 2016). Given the historical past of Germany and its present federal administration structure, it is necessary to highlight its homogeneity. The use of ganz Deutschland in the examples seems to serve the purpose of constructing a sense of collectivity within discourse.

On the other hand, concordance lines for the two-word cluster nach Deutschland [to Germany] demonstrate that Germany is constantly depicted as a destination for foreigners such as immigrants and refugees:

(15) Die ersten Gastarbeiter kamen ab 1955 nach Deutschland. (OK, p. 41) From 1955 the first guest workers came to Germany.

(16) Vor einiger Zeit sind Sie aus Ihrem Heimatland oder einem anderen Land nach Deutschland gekommen. (60SD, p. 74)

Some time ago you have come to Germany from your homeland or a different country.

(17) In den 1980er- und 1990er-Jahren kommen politische Flüchtlinge aus verschiedenen Ländern nach Deutschland und bitten hier um „politisches Asyl". (ZO, p. 38)

In the 1980s and 1990s political refugees from different countries come to Germany and ask for political asylum.

(18) Ich bin mit meiner Familie 2005 aus dem Irak nach Deutschland gekommen. (OK, p. 52)

In 2005 I have come to Germany from Iraq with my family. 
In Examples 16 and 18, the verb gekommen [come (past participle)] co-occurs with nach Deutschland. As Table 5 shows, gekommen is a top collocate of Deutschland at $\mathrm{N}+1$ (t-score $\approx 3.11)$. In fact, intercultural coexistence (interkulturelles Zusammenleben) is a topic of the Orientierungskurs. These cooccurring words (nach, Deutschland, gekommen) help to construe the cultural diversity or pluralism of Germany.

Before proceeding to the analysis of the keywords in other dimensions, I would like to examine the collocate ist ([is]) of Deutschland (at $\mathrm{N}+1$ ), as the collocation analysis illustrates a very high level of association ( $\mathrm{t}$-score $\approx 5.43$ ) between these two words. It is found that when ist occurs on the immediate right of Deutschland, the writers are trying to define what Germany is:

(19) Deutschland ist eine Demokratie mit freien und geheimen Wahlen. (OK, p. 8).

Germany is a democracy with free elections by secret ballot.

(20) Die Bundesrepublik Deutschland ist ein föderalistischer Staat. (ZO, p. 26) The Federal Republic of Germany is a federalist country.

(21) Deutschland ist ein Sozialstaat. (60SD, p. 14) Germany is a welfare state.

(22) Deutschland ist ein Rechtsstaat, d.h. auch der Staat muss sich an Gesetze halten. (ZO, p. 9)

Germany is a constitutional state, that is, the state has to comply with the law as well.

As Flowerdew (1992) pointed out, definitions are common in academic discourse. It is unavoidable for writers of textbooks to define terms. Again here, a critical lens can be adopted to interpret the use of definitions. Van Leeuwen (2008, p. 116) noted that definition constitutes a strategy of "theoretical rationalization" which facilitates the discursive construction of legitimation. A definition decomposes an abstract concept into more concrete ideas and during this process of decomposition, specific features of the abstract concept have to be foregrounded while the rest are excluded. Which features are highlighted would have a significant ideological implication. As the examples above exhibit, Germany is defined in terms of eine Demokratie [a democracy], ein föderalistischer Staat [a federalist country], ein Sozialstaat [a welfare state] and ein Rechtsstaat [a constitutional state]. This means that the target readers are likely to be socialized into such conceptualization of Germany. Furthermore, in comparison with "modalized assertions," using the finite verb ist [is] as a syntactic means to define Germany (viz., "non-modalized assertions") is considered to be "less dialogical" (Fairclough, 2003, p. 47). As Fairclough (2003, p. 61) commented, reducing the 
level of "dialogicality" in discourse is a way to achieve hegemony because the propositions conveyed are harder to contest.

Now let us turn our attention to the common nouns (Staat [nation, country], Kurs [course, class], Gesetze [laws, legislation (plural)], Menschen [people (plural)] and Kinder [children (plural)]) in the keyword list presented in Table 2. Concordance lines indicate that Gesetze and Menschen occur in a wide range of contexts so it is difficult to make generalizations about the use of these words in the corpus. Because of this, they are not included in the discussion. In German, ein Staat can mean a nation, a country or even a state. This keyword is categorized under Dimension 1 (Government) in Table 3 because within the corpus the word Staat is repeatedly used to impersonalize the German government:

(23) Der Staat kümmert sich um seine Bürger, z.B. in sozialen Notlagen. ( $Z O$, p. 75)

The state takes care of its citizens, for example, in social hardships.

(24) Die Wirtschaftsform in Deutschland nennt man soziale Marktwirtschaft. Sie richtet sich nach Angebot und Nachfrage, aber der Staat sorgt für sozialen Ausgleich. (OK, p. 86)

The economic system in Germany is named social market economy. It is directed by supply and demand, but the state ensures social justice.

(25) Der Staat schützt die Ehe und die Familie. (OK, p. 55)

The state protects the marriage [married couples] and the family.

It can be seen from Examples 23 to 25 that the state (or the German government) is represented as an actor that looks after members of the society, as evidenced by the material processes ${ }^{9}$ kümmert sich um [takes care of], sorgt für [ensures] and schützt [protects]. Indeed, collocation analysis reveals that deontic modality muss [has to] and $\operatorname{darf}$ [must] has a propensity to occupy the $\mathrm{N}+1$ position of the keyword Staat (t-score $\approx 2.50$ for muss; $\mathrm{t}$-score $\approx 2.34$ for darf):

(26) Der Staat darf die Menschen nicht körperlich verletzen oder die Todesstrafe einführen. (OK, p. 12)

The state must not physically hurt the people or implement the death penalty.

(27) Der Staat muss die Religionsfreiheit beachten und darf nicht über die Kirche inhaltlich bestimmen. (60SD, p. 79)

The state has to respect the freedom of religion and must not appraise the church contentwise.

9 The Hallidayan way of classifying verbs. For details, refer to the work of Halliday and Matthiessen (2014). 
To sum up, the "collocational profile" of the word Staat in the corpus helps to project a positive image of the German government as one that plays a major role in safeguarding the interests of its citizens. This image is further reinforced when we look at the concordance lines for Kinder [children (plural)]. The word Kinder tends to occur in contexts where education and parents' duty of care are mentioned:

(28) In der Bundesrepublik gilt für alle Mädchen und Jungen die Schulpflicht: $A b$ sechs Jahren müssen alle Kinder in die Schule gehen. (ZO, p. 49)

In the Federal Republic compulsory education applies to all girls and boys. From 6 years [of age] all children have to go to school.

(29) Die Fürsorge und Erziehung ist die wichtigste Pflicht der Eltern. Der Staat passt auf und greift ein, wenn Eltern ihre Kinder nicht gut versorgen oder sie schlecht behandeln. (60SD, p. 20)

Childcare and parenting is the most important duty of parents. The state pays attention and intervenes if parents do not cater for their children well or [they] treat them badly.

In Example 28, the deontic modality müssen [have to] is employed again. The two instances of the determiner alle [all] emphasizes the universality of schooling for children in Germany, irrespective of the gender. In Example 29, the superlative wichtigste [most important] is identified. In Martin and White's (2005, p. 141) terminology, the "force" of the necessity to care for children in society is "upscaled." Also, the conditional clause wenn Eltern ... sie schlecht behandeln [if parents ... treat them badly] creates a hypothetical world in which the assistance from the state is deemed essential. The role of the state as a social gatekeeper is fortified.

Unlike the keywords which have been discussed so far, the keyword Kurs [course, class] performs a completely different function in the textbooks. A significant collocate ( $\mathrm{t}$-score $\approx 9.47$ ) of Kurs at $\mathrm{N}-1$ is $\mathrm{im}^{10}$ [in the]. The two-word cluster im Kurs [in the course or in class] is often found in the instructions for the various exercises stipulated in the textbooks, as shown by the following examples: (30) In welchen Situationen werden Grundrechte verletzt? Diskutieren Sie im Kurs. (OK, p. 12)

In which situations are the basic rights infringed? Discuss in the course [/in class].

(31) Was ist typisch für die deutsche Kultur? Sprechen Sie darüber im Kurs. (ZO, p. 54)

${ }^{10}$ In German, im is the contracted form of the definite article dem [the] when preceded by the preposition in [in] (Durrell, 2011, p. 63). 
What is typical for [of] the German culture? Talk about this in the course [/in class].

In contrast to the keywords like $D D R$, Deutschland and Staat which indicate the specificity of the subject contents which participants of the Orientierungskurs are expected to master, the keyword Kurs marks the general pedagogic nature of textbooks for students. Semantically, the two-word cluster im Kurs refers to the Orientierungskurs itself or the period of time in which students are learning at school. However, from the perspective of pragmatics, the use of im Kurs, as demonstrated by Examples 30 and 31, directs readers' attention to their role as a learner. Besides, the referent of the expression im Kurs may vary because not all the readers are taking the course at the same time or in the same place. Hence, I would argue that im Kurs here is an "indexical expression." As Levinson (2004, p. 102) elucidated, the key of "indexicality" in communication is to draw the addressee's attention to some characteristics of the spatio-temporal physical setting. This remark echoes the use of im Kurs in the corpus of the present research.

The analysis about the keyword Kurs as a device to engage readers is reminiscent of the notion of "metadiscourse" discussed by Hyland (2005). As he wrote, "metadiscourse" is a prevalent term in research on language education and it stems from the idea that writing is a form of "social engagement." "Metadiscourse" concerns how writers articulate and construct interactions so as to convey both information and attitudes (p. 3). Hyland (2005, p. 49) presented a framework to analyze "metadiscourse." Under this framework, there are two main types of "metadiscourse resources" - "interactive" and "interactional." The former refers to linguistic devices which guide readers through the text (e.g., connectors like "in addition" and "furthermore") whereas the latter encompasses those which "involve" readers in the text (e.g., overt reference to the writer with the first person pronoun). In fact, looking at the 9 dimensions of the keywords which I suggested in Table 3, I found that in addition to the one with Kurs (Dimension 9: Learning), the keywords in four other dimensions can be considered "metadiscourse resources" as well. They are Dimension 2 (Processes), Dimension 5 (Question word), Dimension 7 (Pronoun) and Dimension 8 (Abbreviated adverbial).

Like Kurs, the keywords in Dimensions 2, 5 and 7 (Ordnen [To order], Kreuzen [To cross], Lesen [To read], Ergänzen [To complete], Welche [Which], Was [What], Sie [you, she, they] ${ }^{11}$ ) tend to occur in the instructions of the exercises. The keywords Ordnen, Kreuzen, Lesen and Ergänzen are used in the imperative mood, as the concordance lines show that all occurrences of these words are followed by

11 Only when "she" and "they" are the first word of a sentence. 
the formal second person pronoun Sie.12 As mentioned earlier in this paper, the case-sensitive keyword search is unable to single out the instances where the third person feminine pronoun sie and the third person plural pronoun sie are subject to initial capitalization at the beginning of a sentence. A manual check was done and it was discovered that such instances constitute a minority (182 out of 1237). This means that Sie as the formal second person pronoun appears 1055 times in the corpus. The occurrences of the imperative verbs and Sie can be seen from the following examples:

(32) Lesen Sie den Text. Welche Aussagen sind richtig? Kreuzen Sie an. ${ }^{13}$ (ZO, p. 52)

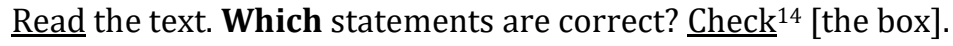

(33) Was bedeutet Artikel 1? Lesen Sie den ersten und wichtigsten Artikel des Grundgesetzes. Unten finden Sie Erklärungen. Welche Erklärung passt zu welchem Absatz? (60SD, p. 17)

What does Article 1 mean? Read the first and most important article of the German constitution. You find explanations below. Which explanation matches which paragraph?

(34) Was sind die Vor- und die Nachteile der sozialen Marktwirtschaft? Was meinen Sie? Sammeln Sie Ihre Ideen im Kurs. (ZO, p. 25)

What are the advantages and the disadvantages of the social market economy? What do you think? Gather your ideas in the course [/in class].

The three examples also display the occurrences of the keywords Welche [Which] and Was [What]. There is no doubt that questions are frequently being posed so that target readers (viz., students) will take part in active learning. In Hyland's (2005, p. 49) terms, the imperative verbs and the second person pronoun can be classified as a specific kind of "interactional metadiscourse resources" called "engagement markers" because through such markers writers are explicitly establishing a relationship with readers. Nevertheless, Hyland (2005, p. 49) did not include question words in his model of "metadiscourse." The empirical evidence of the current research demonstrates that question words, when used by

12 For information about the formation of the imperative in German, refer to the work of Durrell (2011, p. 313).

13 To be more specific, the verb here is Kreuzen ... an (infinitive form: ankreuzen). Ankreuzen means "to check the appropriate box." This is an example of German separable verbs, which consist of a prefix and a "root" verb. On specific occasions the prefix is separated from the "root" verb. Separable verbs are supposed to carry a different meaning from the corresponding "root" verb (Durrell, 2011, p. 233). AntConc 3.5.0 does not identify separable verbs automatically. Manual checks are needed. In the corpus of the present research, all instances of Kreuzen are in fact the separable verb Ankreuzen.

14 In English, the second person pronoun is omitted in the imperative mood. 
textbook writers, have an "engagement" effect too. This finding may help to enrich Hyland's framework.

Last but not least, the keyword z.B. [e.g.] is the abbreviated form of the adverbial zum Beispiel [for example]. Within the corpus, it is used 144 times and ranks third in the keyword list (keyness $\approx 1307.930$ ), indicating its tendency to be over-used. Two examples are shown below:

(35) Die Gemeinden regeln außerdem Dinge, die besonders für ihre Einwohner/innen wichtig sind. Sie kümmern sich z.B. um die Strom- und Wasserversorgung, die Abfallbeseitigung, die Jugendarbeit und um Bildungs- und Freizeitangebote. (60SD, p. 11)

The municipalities also regulate things which are especially important for its inhabitants. They take care of, for example [e.g.], the power and water supply, the waste disposal, the youth work and education and leisure attractions.

(36) In Bürgerinitiativen versammeln sich oft Bürger eines Ortes, um ein bestimmtes Ziel zu erreichen. Es gibt Bürgerinitiativen für z.B. mehr Kinderspielplätze, für die Erhaltung von Naturschutzgebieten oder gegen den Bau von Straßen oder Industriegebieten. (OK, p. 30)

In citizens' initiatives [or action groups] citizens of one place often gather together in order to reach a particular goal. There are citizens' initiatives [or action groups], for example [e.g.], for more children's playgrounds, for the conservation of nature reserves or against the construction of roads or industrial areas.

Instead of being an "engagement marker," z.B. belongs to a type of "interactive metadiscourse resources" known as "code glosses." As Hyland (2005, p. 50-52) commented, "interactive metadiscourse resources" are utilized by writers to organize information so that it can be understood by target readers. These linguistic resources also reflect writers' estimation of the readers' "knowledgebase." In Examples 35 and 36, z.B. is employed to introduce extra information which from the writers' viewpoint can facilitate readers' understanding of Gemeinden [municipalities] and Bürgerinitiativen [citizens' initiatives or action groups] respectively. On top of the pedagogic implication, it can be argued that the use of z.B. has an ideological undertone. As Jeffries (2010, pp. 67-70) maintained, using phrases like "for instance" and "for example" to elaborate on something in text (viz., "exemplification") may boost readers' confidence on the quality of the text as it appears to be more thorough and less ambiguous.

\section{Conclusion}

To research how immigrants in Germany are socialized into the host society at the institutional level, three textbooks written for participants of the orientation 
course have been investigated. Tools from corpus linguistics have been utilized to analyze the data. The keyword list has been generated and the "collocational profiles" of important keywords have been studied. Manual checks on the concordance lines have been performed to determine any ideological and pedagogic characteristics of the textbooks.

The top keywords of the corpus generally echo the nature of the orientation course, which is supposed to equip immigrants with knowledge of the German politics, history and culture. One may argue that some of the keywords (e.g., Bundesrepublik [Federal Republic] and Deutschland [Deutschland]) are predictable, given the contents of the corpus. Nevertheless, collocation analysis of the keywords has provided us with many insights into the discursive representation of Germany and its ideological effects. First, it has been shown that $D D R$ [German Democratic Republic (GDR), aka East Germany] co-occurs frequently with Bundesrepublik Deutschland in contexts where the reunification is underscored. A negative "semantic prosody" has been noted from the concordance lines for $D D R$. A multitude of linguistic strategies are deployed to portray the GDR as an undesirable entity. For instance, "explicit opposition" and "comparative opposition" (Jeffries, 2010) are used to juxtapose the "bad" GDR with the "good" Federal Republic of Germany whereas equivalence between the GDR and the Nationalsozialismus [Nazi] is forged by presenting them as the co-hyponyms of Einparteienstaat [one-party state]. It has been argued that these linguistic strategies, together with the negatively connoted lexis surrounding $D D R$, are used to legitimize the German reunification, which actually means the official dissolution of the GDR as it "joined" the Federal Republic of Germany. On the other hand, the collocational patterns displayed by the keyword Deutschland construe contemporary Germany as a popular destination for foreigners (e.g., the threeword cluster nach Deutschland gekommen [come to Germany]). A sense of collectivity is also constructed by emphasizing the unity of Germany (viz., the cooccurrence of ganz [all, whole] and Deutschland). Furthermore, the keywords Staat [state] and Kinder [children] tend to collocate with deontic modality (muss [has to] and $\operatorname{darf}$ [must]) and lexis associated with care and protection, thus projecting an image of Germany as a nurturing welfare state.

As remarked in the introduction of this paper, the orientation course is an official means to diffuse specialized knowledge about Germany into a foreign population. The textbooks examined in this study signify the (re-)production of such knowledge. Which knowledge to (re-)produce is highly dependent on the decision of the textbook writers, who to a great extent are constrained by the governing party, as the contents of the textbooks are derived from the 300 questions designed for the "Living in Germany" (Leben in Deutschland) examination (Federal Office for Migration and Refugees, 2016a). What I would like to highlight through the present research is that learning such knowledge also 
implies acquisition of particular world views (i.e., the dominant ideologies in this case), of which the immigrants may be unaware.

Another contribution of the current study is that analysis of the keywords has informed us of the pedagogic character of the textbooks. It has been found that certain keywords (e.g., the imperative verbs, Sie [you (formal)], Kurs [course, class] and z.B. [e.g.]) can be classified as "metadiscourse resources" (Hyland, 2005). The concordance lines have shown that these "metadiscourse resources" are mostly "engagement markers" which direct readers' attention to their role as a learner or a participant in the orientation course. Although question words (Welche [Which] and Was [What]) are not included in Hyland's (2005) framework, they are used as a tool to "involve" readers into the text as well. Analysis of the keyword z.B. [e.g.] bridges the gap between the ideological and the pedagogic facets of the textbooks examined. While this "code gloss" is supposed to organize information in discourse so as to facilitate readers' comprehension, it simultaneously marks writers' assumption of readers' "knowledge-base." Along the line of critical stylistics (Jeffries, 2010), using for example or similar expressions to exemplify ideas in texts can be seen as a strategy to increase readers' trust on the texts, making them less doubtful about the propositions presented. This finding concerning a mixture of ideological and pedagogic implications arising from the use of certain lexical items in textbooks opens up a space for future corpus-based research on this genre.

\section{References}

Anthony, Laurence. (2015). AntConc (Version 3.5.0) [Computer Software]. Tokyo, Japan: Waseda University. Available from http://www.laurenceanthony.net/

Bottici, Chiara, \& Challand, Benoît. (2013). Imagining Europe: Myth, memory, and identity. New York: Cambridge University Press.

Byram, Michael (Ed.). Germany: Its representation in textbooks for teaching German in Great Britain. Frankfurt: Diesterweg.

Cheng, Winnie. (2012). Exploring corpus linguistics: Language in action. Abingdon: Routledge.

Culpeper, Jonathan, \& Demmen, Jane. (2015). Keywords. In Douglas Biber \& Randi Reppen (Eds.), The Cambridge Handbook of English corpus linguistics (pp. 90105). Cambridge: Cambridge University Press.

Durrell, Martin. (2011). Hammer's German grammar and usage (5th ed.). London: Hodder Education.

Fairclough, Norman. (2003). Analyzing discourse: Textual analysis for social research. London: Routledge.

Federal Office for Migration and Refugees. (2016a). Gesamtfragenkatalog zum Test „Leben in Deutschland”. Retrieved May 25, 2016, from http://www.bamf.de/SharedDocs/Anlagen/DE/Downloads/Infothek/Integra 
tionskurse/Kurstraeger/Testverfahren/gesamtfragenkatalog-

lebenindeutschland.pdf?_blob=publicationFile

Federal Office for Migration and Refugees. (2016b). Integrationskurse. Retrieved

May 23, 2016, from http://www.bamf.de/DE/Willkommen/DeutschLernen/Integrationskurse/in tegrationskurse-node.html

Federal Office for Migration and Refugees. (2016c). Zertifikat Integrationskurs.

Retrieved May 23, 2016, from http://www.bamf.de/DE/Willkommen/DeutschLernen/Integrationskurse/A bschlusspruefung/ZertifikatIntegrationsKurs/zertifikatintegrationskursnode.html

Federal Statistical Office of Germany. (2016). Ausländische Bevölkerung am 31.12.2015. Retrieved May 23, 2016, from https://www.destatis.de/DE/ZahlenFakten/GesellschaftStaat/Bevoelkerung/ MigrationIntegration/AuslaendischeBevolkerung/Tabellen/Bundeslaender.ht $\mathrm{ml}$

Flowerdew, John. (1992). Definitions in science lectures. Applied Linguistics, 13(2), 202-221.

Fraysse-Kim, Soon Hee. (2010). Keywords in Korean national consciousness: A corpus-based analysis of school textbooks. In Marina Bondi \& Mike Scott (Eds.), Keyness in texts (pp. 219-234). Amsterdam: John Benjamins.

Gerbig, Andrea. (2010). Key words and key phrases in a corpus of travel writing:

From Early modern English literature to contemporary "blooks". In Marina Bondi \& Mike Scott (Eds.), Keyness in texts (pp. 147-168). Amsterdam: John Benjamins.

Halliday, Michael, \& Matthiessen, Christian. (2014). Halliday's introduction to functional grammar (4th ed.). Abingdon: Routledge.

Hong, Huaqing, \& He, Xianzhong. (2015). Ideologies of monoculturalism in Confucius Institute textbooks: A corpus-based critical analysis. In Xiao Lan Curdt-Christiansen \& Csilla Weninger (Eds.), Language, ideology and education: The politics of textbooks in language education (pp. 90-108). New York: Routledge.

Hutter, Will. (2015, August 30). Angela Merkel's humane stance on immigration is a lesson to us all. The Guardian. Retrieved May 23, 2016, from http://www.theguardian.com/commentisfree/2015/aug/30/immigrationasylumseekers-refugees-migrants-angela-merkel

Hyland, Ken. (2005). Metadiscourse: Exploring interaction in writing. London:

Continuum.

Jaworska, Sylvia, \& Krishnamurthy, Ramesh. (2012). On the F word: A corpusbased analysis of the media representation of feminism in British and German press discourse, 1990-2009. Discourse \& Society, 23(4), 401-431. 
Jeffries, Lesley. (2010). Critical stylistics: The power of English. Basingstoke: Palgrave Macmillan.

Krummes, Cédric. (2013). "internet-de" German Frequency List (Mixed Case) [Electronic Resource]. Leipzig: Leipzig Universität.

Kupferberg, Feiwel. (2002). The rise and fall of the German Democratic Republic. New Brunswick: Transaction Publishers.

Lam, Phoenix. (2009). Discourse particles in corpus data and textbooks: The case of well. Applied Linguistics, 31(2), 260-281.

Levinson, Stephen. (2004). Deixis. In Laurence Horn \& Gregory Ward (Eds.), The handbook of pragmatics (pp. 97-121). Malden: Blackwell.

Lipinski, Silke. (2010). A frequency analysis of vocabulary in three first-year textbooks of German. Die Unterrichtspraxis / Teaching German, 43(2), 167174.

Martin, James, \& White, Peter. (2005). The language of evaluation: Appraisal in English. Basingstoke: Palgrave Macmillan.

Moser, Franziska, \& Hannover, Bettina. (2014). How gender fair are German schoolbooks in the twenty-first century? An analysis of language and illustrations in schoolbooks for mathematics and German. European Journal of Psychology of Education, 29(3), 387-407.

Neary-Sundquist, Colleen. (2015). Aspects of vocabulary knowledge in German textbooks. Foreign Language Annals, 48(1), 68-81.

Sharoff, Serge. (2006). Creating general-purpose corpora using automated search engine queries. In Marco Baroni \& Silvia Bernardini (Eds.), Wacky! Working papers on the web as corpus (pp. 63-98). Bologna: GEDIT.

Sinclair, John. (2003). Reading concordances: An introduction. Harlow: Longman.

Snider, Daren. (2005). Communicative and non-communicative activities in firstyear college German textbooks. Die Unterrichtspraxis / Teaching German, 38(2), 163-171.

van Dijk, Teun. (2008). Discourse and power. Houndmills: Palgrave Macmillan.

van Dijk, Teun. (2014). Discourse and knowledge: A sociocognitive approach. Cambridge: Cambridge University Press.

van Leeuwen, Theo. (2008). Discourse and practice: New tools for critical discourse analysis. Oxford: Oxford University Press.

Vanstone, Jeremy, \& Mennecke, Arnim. (1993). Deutsch konkret: Ein Lehrwerk für Jugendliche. In Michael Byram (Ed.), Germany: Its representation in textbooks for teaching German in Great Britain (pp. 63-113). Frankfurt: Diesterweg.

Wegmann, Kate. (2014). Shaping a new society: Immigration, integration, and schooling in Germany. International Social Work, 57(2), 131-142.

Wolf, Hans-Georg, \& Juffermans, Kasper. (2008). Conceptions of globalization in African and Western newspaper corpora: A case study. In Hans-Georg Wolf, Lothar Peter \& Frank Polzenhagen (Eds.), Focus on English: Language structure 
and language variation: Studies in honor of Peter Lucko (pp. 133-149). Leipzig: Leipziger Universitätsverlag.

Wood, David, \& Appel, Randy. (2014). Multiword constructions in first year business and engineering university textbooks and EAP textbooks. Journal of English for Academic Purposes, 15, 1-13.

The World Factbook. (2016). Europe: Germany. Retrieved May 20, 2016, from https://www.cia.gov/library/publications/the-world-factbook/geos/gm.html

\section{Contact}

Mr Ray C. H. Leung

Department of English and American Studies

University of Potsdam

Am Neuen Palais 10

14469 Potsdam

Germany

chungleungde@gmail.com 